of these kingdoms is organized into Registration Associations - when, by their agency, the name of every quack in the country is notified to the registrars - when the common enemy is driven beyond the circum vallum of the profession, then let us settle our differences on their merits, and not before. I am, Sir, your obedient servant,

October, $18 \tilde{8} 8$ Henky Holmes, M.D.

\title{
GALVANISM IN DENTISTRY.
} To the Editor of THE LANCET.

SIR,-Instead of leaving London this autumn, I have been extensively engaged in experiments with the electro-galvanic current for dental operations. The idiosyncrasies of patients being very different, the electro-gal vanic shock varies in its intensity; and I do not recommend those acted upon with difficulty to test the strength of shock necessary, in their peculiar cases, to anæsthetic purposes. From statistics, I am not far wrong in averaging adults sensible of the pain of extraction under the galvanic current at three to one; while in the cases of children np to twelve years of age the numbers may be reversed,-viz., one to three.

The following hints may not be considered useless at this moment,- - viz.: Operators should consider the constitutions of their patients, and operate on none subject to epilepsy, or to disease of the heart or brain. 2nd. Medical sanction should be obtained prior to undergoing the double shock of electrogalvanism and extraction. 3rd. The intensity of the shock should be measured by the electrometer. Lastly : Practitioners should not draw and put forth hasty conclusions from a few isolated cases, but wait till such time as electro-galvanism shal have been assiduously tested by themselves, and experimented also by others fully capable of giving its merits and its failures their fnll and separate consideration.

I am, Sir, your obedient serrant,

Old Burlington-street, Oct. $180 \overline{8}$. George WaIte

\section{NEW MEDICAL WARRANT FOR THE ARMY.}

For the future there are to be only four ranks in the Army Medical Department:-

Inspector-General.

Deputy Inspector-General.

Surgeon, Regimental or Staff.

Assistant-Surgeon.

Assistant-surgeon ranks as lieutenant; after five years' ser. vice, as captain.

Surgeon, as major; after two years' service, as lieutenantcolonel, but junior of the rank, and then styled surgeon-major.

Deputy inspector-general, as lieutenant-colonel; after five Jears, as colonel.

Inspector-general, as colonel; after five years, as brigadiergeneral.

TULX:PAX.

Assistant-surgeon, on appointment

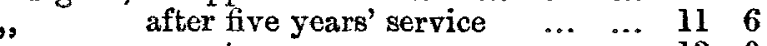

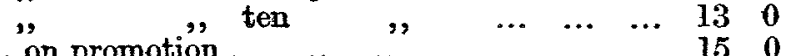

Sargeon, on promotion ... $\begin{array}{cccccccc}9 \quad \text { after fifteen years' service } & \ldots & \ldots & \ldots & \ldots & 18 & 0 \\ \text { twenty } & \ldots & \ldots & \ldots & \ldots & \ldots & 22 & 0\end{array}$

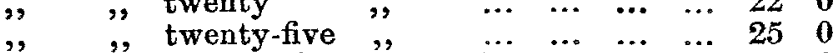

Deputy-inspector-general, on promotion $\ldots$...

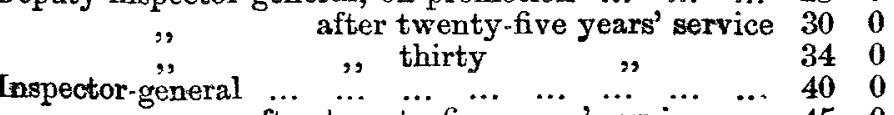

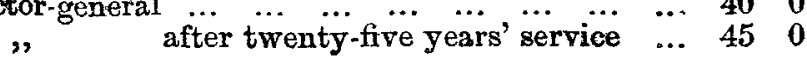
HALF-PAY.

If the officer has attained the age of fifty-five in the ranks of surgeon (major), surgeon, or assistant-surgeon, or sixty-five in that of deputy-inspector or inspector, he is obliged to retire.

All officers can claim retirement after twenty-five years' service, on seven-tenths of the rate of pay they are in receipt of.

The medical officers are now, as to advantages of rank, honours, widows' pensions, \&c. \&c., placed on exactly the same footing as military officers, aceording to their relative rank, - thanks to General Peel and the present talented Director-General of the Army Medical Department.

\section{MEDICAL REGISTRATION ASSOCIATIONS.}

\section{NOTTINGHAM MEDICAL REGISTRATION ASSOCLATION. \\ To the Editor of THE LANCET.}

SIR,-I beg to forward the following resolutions, which were passed at a meeting of legally-qualified members of the medical profession, which was held this day at the Dispensary, Nottingham, Mr. Eddison in the chair.-I am, Sir, yours \&c.,

Pelham-street, Nottingham, Oct. 1858.

Thomas Wrigeti.

Proposed by Mr. Stanger, and seconded by Mr. Truman, - That it is expedient to form an Association of duly-qualified medical men, practising in Nottingham and Nottinghamshire, to assist the Registrar to carry out the provisions of the new Medical Act."

Proposed by Dr. Robernson, and carried by acclamation," That a subscription of two shillings and sixpence be entered into to defray the necessary expenses of "The Nottinghamshire Medical Registration Association."

Proposed by Dr. Thompson, of Newark, and seconded by Mr. CoourBe, of Basford, - "That a committee be formed to carry out the objects of this Association, and to call a general meeting of members whenever it may be considered necessary."

Proposed by Mr. STAxger, and seconded by Mr. WORTH,"That the following be members of the committee, with power to add to their number :-Mr. Eddison, Mr. T. Wright, Dr. Wilson, Mr. White, Mr. Stanger, Mr. Ellam, Mr. Coombe, of Basford ; Dr. Thompson, of Newark; Mr. Scott, of Mansfield ; and Mr. Butler, of Beeston."

Proposed by Mr. STEPHenson, and seconded by Mr. J. M. Thompson, -..."That the above resolutions be forwarded to the medical journals."

Proposed by Dr. Wilsos, and seconded by Mr. T. WRIGHT, - "That the thanks of the meeting be given to the chairman."

ThoMas WRIGHT, Secretary and Treasurer.

\section{THORNE AND GOOLE MEDICAL REGISTRATION ASSOCIATION}

A MEETING of medical practitioners was held on the 12th inst., in the Court-House, J. J. Littlewood, Esq., M.R.C.S. E., in the chair. Resolutions were unanimously passed, forming a Society, to be called the "Thorne and Goole Medical Registration Association," the objects being to assist the Registrar in working the Medical Act passed last session; watching the regis tration; preparing correct lists of all legally-qualified practitioners, as well as of unqualified men in the district; and using the most efficient means for protecting alike the interests of the public and of the profession, by preventing, as far as possible, all illegal practice. R. Gillard, Esq., M.R.C.S.E., was appointed Honorary Secretary. A resolution was passed, inviting the members of the profession resident in the Doncaster district to join the Association in the event of their not forming one of their own. All gentlemen entitled to be registered under the Act are eligible as members of the Association.

\section{HERTS MEDICAL REGISTRATION SOCIETY.}

ON Friday, the lst inst., a public meeting of members of the medical profession residing in the county of Hertford, was held at the Dimsdale Arms Inn, for the purpose of taking into consideration the means to be adopted to give effect to the provisions of the New Medical Reform Act, which came into opera. tion on that day. J. Davis, Esq., M.D., of Hertford, was unanimously called to the chair. Amongst the members of the profession present were, Dr. R. D. J. Evans, Dr. Mackay, Dr. Towers, Dr. Woodhouse, and Mr. Odell, of Hertford ; Dr. Hill Smith, of Stevenage; Mr. O. Foster, of Hitchin ; Mr. Bowden, of Ware; Mr. Dunn, of Baldock; Mr. Stevens and MIr. Horley, of Hoddesdon ; Dr. Drage, of Hatfield; Mr. Baldwin, of Bark. way; Mr. Gaffney, of Buntingford; and Mr. Webb, of Welwyn. Letters had been received from sixteen other medical men of the county, expressing their anxiety to co-operate in the formation of a society to carry out the new law, which they regarded as a great boon to the profession.

It was unanimously arreed to form a society, to be called the "Herts Medical Registration Society." Dr. Davies, of Hertford, was appointed president; Mr. O. Foster, of Hitchin, treasurer; Mr. W. J. Bowden, of Ware, secretary; and the following gentlemen were appointed, together with the officers of the Society, as a committee (three of their number to form a 